\title{
When to repair coarctation associated with hypoplastic aortic arch through the front: Are we asking the questions that really matter?
}

\author{
Petros V. Anagnostopoulos, MD, MBA
}

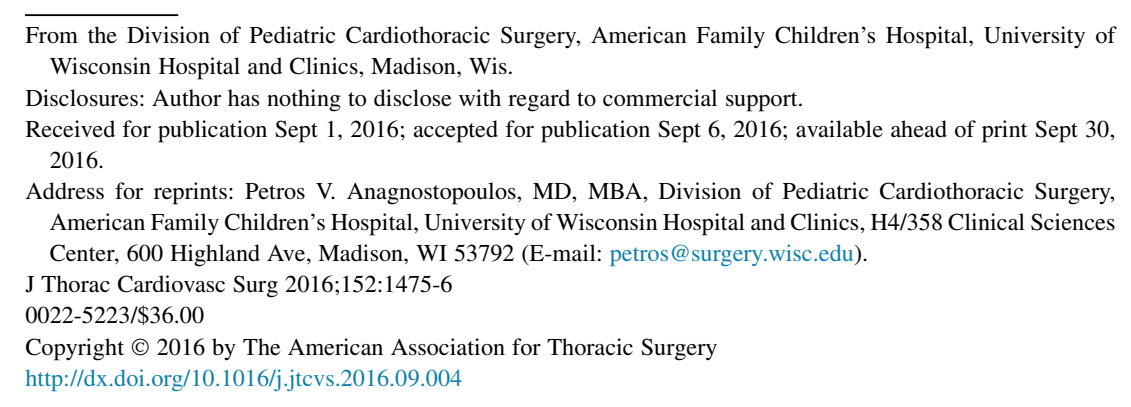

A common dilemma in clinical practice is whether to approach a patient with coarctation of the aorta and arch hypoplasia (CoA-AH) through a thoracotomy or median sternotomy with cardiopulmonary bypass (CPB). ${ }^{1}$ A key issue is that there is no uniformly accepted definition of arch hypoplasia and no consensus on the degree of hypoplasia that is severe enough to warrant surgical repair. ${ }^{1-3}$ Diagnosis is made by echocardiogram, where measurements are operator-dependent. The importance of the branching patterns of the arch and of the distance between branches have not been systematically studied. When there is an associated intracardiac lesion, most surgeons favor single-stage repair through the front. However, if the arch is the only issue, the decision becomes more complicated. Practices generally differ according to institutional bias, surgeon experience, and surgeon preferences. Lessons learned from reported surgical series can be difficult to extrapolate.

Tulzer and colleagues ${ }^{4}$ reported midterm outcomes on 183 patients with CoA-AH. Sternotomy was used in 72 patients (71 with $\mathrm{CPB}$ and 56 with double arterial perfusion). The 30-day mortality for the entire cohort was impressively low $(0.54 \%)$. One thoracotomy patient developed paraplegia. There were no deaths on median follow-up of 6.3 years. Eleven patients developed recoarctation. These patients had significantly lower $z$ scores of the transverse arch (10 repaired through thoracotomy). Eight were successfully managed in the cath lab. The ideal cutoff $z$ score value of the proximal arch to perform a repair through a left lateral thoracotomy was -4.59 .

The clinical results in this article are remarkable. However, one cannot help but wonder: Is it time to abandon mortality and risk of reintervention as the sole deciding factors in the choice of surgical strategy? The mortality should be low irrespective of approach. ${ }^{5}$ Even if one decides

\section{References}

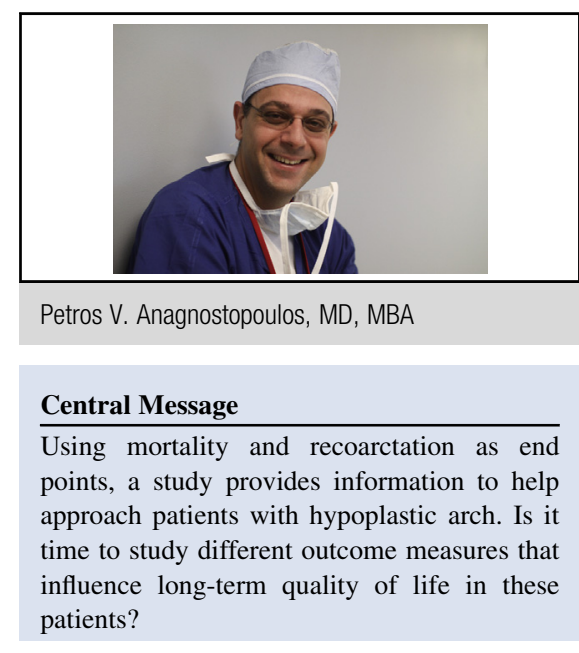

See Article page 1506.

to repair CoA-AH through a thoracotomy and the repair results in recurrent coarctation, most can be addressed in the cath lab successfully with low risk. Will such a suboptimal outcome prove to be superior to that of a patient who has perfect anatomic repair but potentially faces adverse neurodevelopmental consequences of a neonatal CPB run? This question becomes more pressing as groups like Tulzer and colleagues ${ }^{4}$ continue to push the limits by using perfusion modifications to avoid deep hypothermia and perform arch reconstructions at $28^{\circ} \mathrm{C}$, a practice that to date results in no immediate neurologic deficits, but for which longterm outcomes are poorly defined. ${ }^{6}$ It may be time to start taking into account not only survival and accuracy of repair, but also the long-term sequelae of our therapies. In this quest it is important to partner with our cardiology colleagues. They are the ones who judge our competence using the quality of our anatomic results. Cardiologists also are the ones who will be caring for patients long after their scars are healed and the weight of our decisions start to define their long-term quality of life.

1. Langley SM, Sunstrom RE, Reed RD, Rekito AJ, Gerrah R. The neonata hypoplastic aortic arch: decisions and more decisions. Sem Torac Cardiovasc Surg Pediatr Cardiac Surg Ann. 2013;16:43-51.

2. Karl TR, Sano S, Brawn W, Mee RB. Repair of hypoplastic or interrupted aortic arch via sternotomy. J Thorac Cardiovasc Surg. 1992;104:688-95.

3. Elgamal MA, McKenzie ED, Fraser CD Jr. Aortic arch advancement: the optimal one-stage approach for surgical management of neonatal coarctation with arch hypoplasia. Ann Thorac Surg. 2002;73:1267-72; discussion 172-3. 
4. Tulzer A, Mair R, Kreuzer M, Tulzer G. Outcome of aortic arch reconstruction in infants with coarctation: Importance of operative approach. J Thorac Cardiovasc Surg. 2016;152:1506-13.

5. Ungerleider RM, Pasquali SK, Welke KF, Wallace AS, Ootaki Y, Quartermain MD, et al. Contemporary patterns of surgery and outcomes for aortic coarctation: an analysis of the Society of Thoracic Surgeons Congenital Heart Surgery Database. J Thorac Cardiovasc Surg. 2013;145:150-7; discussion 157-8.

6. Hammel JM, Deptula JJ, Karamlou T, Wedemeyer E, Abdullah I, Duncan KF. Newborn aortic arch reconstruction with descending aortic cannulation improves postoperative renal function. Ann Thorac Surg. 2013;96:1721-6; discussion 6.

Access to The Journal of Thoracic and Cardiovascular Surgery Online is reserved for print subscribers!

Full-text access to The Journal of Thoracic and Cardiovascular Surgery Online is available for all print subscribers. To activate your individual online subscription, please visit The Journal of Thoracic and Cardiovascular Surgery Online, point your browser to http://www.mosby.com/jtcvs, follow the prompts to activate your online access, and follow the instructions. To activate your account, you will need your subscriber account number, which you can find on your mailing label (note: the number of digits in your subscriber account number varies from 6 to 10). See the example below in which the subscriber account number has been circled:

\section{Sample mailing label}

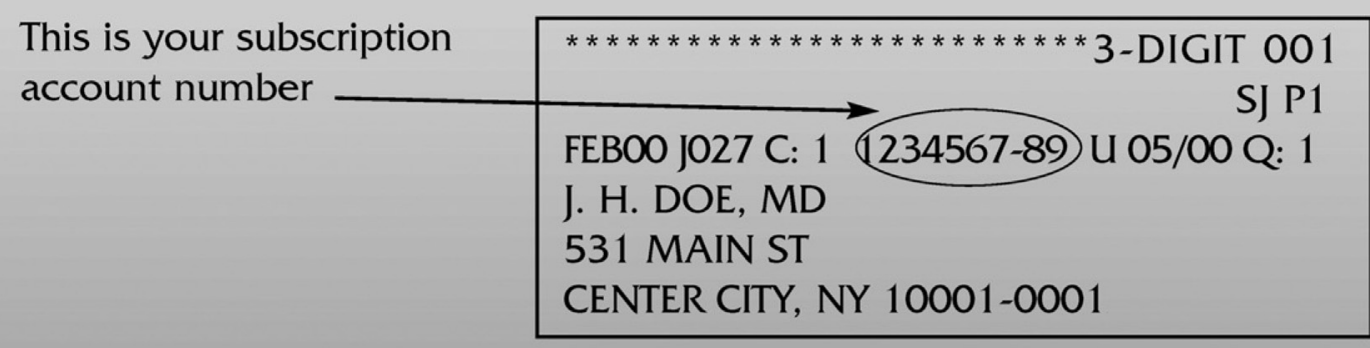

Personal subscriptions to The Journal of Thoracic and Cardiovascular Surgery Online are for individual use only and may not be transferred. Use of The Journal of Thoracic and Cardiovascular Surgery Online is subject to agreement to the terms and conditions as indicated online. 